\title{
İsrail'de Liberal Demokratlığın ve Etnik Milliyetçiliğin İdeolojik Yansıması: Post-Siyonizm ve Neo-Siyonizm
}

\author{
The Ideological Reflection of Liberal Democracy and Ethnic \\ Nationalism in Israel: Post-Zionism and Neo-Zionism
}

Tuğçe ERSOY CEYLAN* iD

\section{Öz}

Siyonizm Yahudilerin de kendi kaderini tayin etme hakkının olduğu esasına ideolojik arka plan inşa etmeyi amaçlayan milliyetçi bir ideolojidir. Bu açıdan Siyonizm’in 19. yüzyılda Avrupa’da ortaya çıkan milliyetçilik fikirlerinin bir ürünü olduğunu söylemek yanlış olmayacaktır. Bu durumda kendi kaderini tayin etme ve kendi ulusuna ait bir devlet kurmak ülküsüyle yola çıkmış olan Siyonizm İsrail'in kurulması ile amacını yerine getirdi ve miadını doldurdu mu? Siyonizm’in miadını doldurduğu tartışması etrafında ortaya atılmış olan sorular yeni Siyonizmler ortaya çıkarmıştır. Klasik ayrışmalardan farklı olarak bu yeni yaklaşımlar Siyonizm'in varoluşuna, temeline ve dolayısıyla İsrail'in kuruluş argümanlarına yönelik tartışmalardır. Bu arka plan ışığında bu çalışmanın amacı İsrail'in kurulmasını takip eden yllarda hem devletin hem de toplumun konsolide olduğu süreçte İsrail akademisinde başlayıp toplumun diğer tabakalarına yayılan ve bugün post-Siyonizm olarak bilinen düşünme biçimini ve ona karşı argüman olarak ortaya çıkan neo-Siyonizm akımını karşılıklı olarak ele almaktır. Çalışmada biri liberal demokratlığın ve sol kanadın (post-Siyonizm) diğeri etnik ayrımcılığın (neoSiyonizm) tezahürü olan bu yaklaşımlar süreç takibi vasıtasıyla ortaya çıktıkları zamandan günümüze kadar tarihsel sosyolojik bir yaklaşımla analiz edilecektir. Makalenin temel argümanı derin kimliksel ayrışmalarla bölünmüş olan İsrail toplumundaki iki ucu temsil eden bu ideolojilerin merkezinde İsrail'in hem işgal altındaki hem de İsrail vatandaşı Filistinlilere uygulamakta olduğu ayrımcı/dışlayıcı politikalar karşısındaki duruş farklılıkları olduğudur.

Anahtar Kelimeler: Siyonizm, Post-Siyonizm, Neo-Siyonizm, İsrail Toplumu, Filistinliler

\begin{abstract}
Zionism is a nationalistic ideology that aims to build an ideological background to the right of the Jews on self-determination. In this respect, it would not be incorrect to argue that Zionism is a product of the ideas of nationalism, burst in $19^{\text {th }}$ century Europe. Then, did Zionism fulfill its mission following the establishment of Israel? Those kinds of questions have revealed new kinds of Zionisms. Unlike classical divergences, those new approaches' arguments are made against Zionism's existence, fundamentals, thus against the establishment of Israel. Within this background, the aim of the study is to analyze comparatively the post-Zionist and neo-Zionist ways of thinking. The study aims to
\end{abstract}

* İzmir Demokrasi Üniversitesi, Uluslararası İlişkiler Bölümü, E-posta: tugce.ersoy@idu.edu.tr 
evaluate post-Zionism and neo-Zionism which are the reflections of liberal democracy and ethnic discrimination respectively via process tracing and with a historical sociology perspective. The main argument of the study is that the main arguments of these ideologies representing the two radical poles of Israeli society which is divided deeply by identity cleavages have taken shape according to their stances vis-à-vis the discriminatory and exclusivist policies against the Palestinians living both inside Israel and in the occupied territories.

Keywords: Zionism, Post-Zionism, Neo-Zionism, Israeli Society, Palestinians

\section{Giriş}

İsrail'in kuruluşu Yahudi tarihi açısından çı̆̆ır açan bir gelişme, tarihi bir andır. İsrail'in kurulmasını mümkün kılan düşünsel arka plan ise Siyonizm olarak nitelendirilmiş olan Yahudi milliyetçiliğidir. Bu açıdan bir fenomen olarak Siyonizm’in ortaya çıkışının ve Yahudilere takip edecekleri belli bir eylem planı sunmuş olmasının da bir dönüm noktası olduğunu belirtmek elzemdir. Siyonizm, Yahudilerin siyasal ve sosyo-ekonomik konumlarını dönüştürmekle kalmamış, Yahudi yaşamındaki her cemaatin, dini hareketin, derneklerin ve kuruluşların gidişatını da etkilemiştir.

Siyonizm muhtelif coğrafyalarda meskûn Yahudilerin içinde bulundukları duruma çözüm olarak geliştirilmiş ilk düşünsel pratik değildi. Ne var ki hem ortaya çıktığı zamandaki siyasi iklimin uygun olması hem de Siyonizm'in kurucusu olan Theodor Herzl'in (1860-1904) hirsı ve sebatı bu ideolojiyi dünya çapında tanınan ve İsrail'i kuran başat ideoloji haline getirmiştir. Bununla beraber, Siyonizm'in yekpare bir ideoloji olduğunu söylemek yanlış olacaktır. Zira Herzl'in öncülük etmiş olduğu klasik Siyonizm zamanla çeşitlenmiştir; çeşitli ülkelerde yaşayan ve buralardaki sosyal ve siyasi çevrelere maruz kalmış olan birçok entelektüel Yahudi, Siyonizm ile içinde yaşadığı siyasi kültürü sentezlemiş, bu sayede yeni Siyonizmler ortaya çıkmıştır. Liberalizm, otoriteryanizm, sosyalizm gibi ideolojiler ve dini inanç Siyonist ideoloji içinde yeni varyantlar oluşmasını sağlamıştır. İşçi Siyonizmi, Revizyonist Siyonizm, Binyılcı - dini Siyonizm gibi klasik Siyonizm'den belli başlı nüanslarla ayrılan yaklaşımlar bahsedilen bu siyasi-kültürel çeşitliliğin etkisiyle şekillenmiştir.

Yahudilerin içerisinde yaşamakta olduğu topluluklardan mütemadiyen dışlandığı ve tabiri caizse persona non grata ilan edildiği gerçeği hemen her dönemde Yahudi din adamlarını ve entelektüelleri topluluklarını bu durumdan nasıl kurtaracaklarını düşünmeye itmiştir. Diğer bir deyişle anti-semitizm hemen hiçbir yerde Yahudilerin peşini bırakmamıştır. Özellikle Batı Avrupa'da 15. yüzyıldan itibaren Yahudilerin münferit saldırılara uğradığı, özellikle İspanya ve Portekiz'de engizisyon tarafından türlü suçlamalarla yargılandıkları vakıadır (Gutierrez, 2017). Ancak bu yaklaşımların çoğu Yahudi sorununa yerinde çözüm aramıştır. Avrupa'daki Yahudi sorununa çözüm için yine orada kök salmış olan milliyetçi ideolojiden medet umulması için Siyonizm'in bir ideoloji ve eylem planı olarak Herzl tarafından ortaya konulması gerekmiştir. Nitekim Siyonizm Yahudilerin de kendi kaderini tayin etme hakkının olduğu esasına ideolojik arka plan inşa etmeyi amaçlayan milliyetçi bir ideolojidir (Shimoni, 1995, s.4). Bu açıdan 
Siyonizm'in 18. yüzyılda Avrupa'da ortaya çıkan milliyetçilik fikirlerinin bir ürünü olduğunu söylemek yanlış olmayacaktır.

O zaman kendi kaderini tayin etme ve kendi ulusuna ait bir devlet kurmak ülküsüyle yola çımış olan Siyonizm İsrail'in kurulması ile amacını yerine getirdi ve miadını doldurdu mu? Eylem planı olarak Siyonist ajanda hayata geçmiş olsa da bir düşünme biçimi veya bir ideoloji olarak Siyonizm'in halen var olduğunu söylemek mümkündür. Siyonizm'in miadını doldurduğu tartışması etrafında ortaya atılmış olan sorular yeni Siyonizmler ortaya çıkarmıştır. Yukarıda değinilen klasik ayrışmalardan farklı olarak bu yeni yaklaşımlar Siyonizm’in varoluşuna, temeline ve dolayısıyla İsrail'in kuruluş argümanlarına yönelik tartışmalardır. Özellikle yeni tarihçiler olarak adlandırılan bir grup araştırmacının İsrail'in kuruluşuna yönelik anlatıyı yeniden yorumladığı post-Siyonist yaklaşım bugün İsrail'de bir kesim tarafından devletin varoluşuna yönelik bir tehdit olarak algılanmaktadır. Bu arka plan ışı̆̆ında bu çalışmanın amacı İsrail’in kurulmasını takip eden y1llarda hem devletin hem de toplumun konsolide olduğu süreçte İsrail akademisinde başlayıp toplumun diğer tabakalarına yayılan ve bugün post-Siyonizm olarak bilinen düşünme biçimini ve ona karşı argüman olarak ortaya çıkan neo-Siyonizm akımını karşılıklı olarak ele almaktır. Çalışmada biri liberal demokratlığın (post-Siyonizm) diğeri etnik ayrımcılığın (neo-Siyonizm) tezahürü olan bu yaklaşımlar süreç takibi vasıtasıyla ortaya çıktıkları zamandan günümüze kadar tarihsel sosyolojik bir yaklaşımla ele alınacaktır. Makalenin temel argümanı derin kimliksel ayrışmalarla bölünmüş olan İsrail toplumundaki iki ucu temsil eden bu ideolojilerin merkezinde İsrail'in hem işgal altındaki hem de İsrail vatandaşı Filistinlilere uygulamakta olduğu ayrımcı/ dışlayıcı politikalar karşısındaki duruş farklılıkları olduğudur.

Çalışma üç bölümden oluşmaktadır. İlk bölümde Siyonizm’in ortaya çıkışı, fikir babaları, tarihsel süreç içinde gelişimi ana hatlarıyla ele alınacaktır. İkinci bölümde İsrail’in kuruluşunu takip eden süreçte Siyonizm’e, rejime ve devletin karakterine yönelik akademide başlayan tartışmalar incelenecek böylelikle post-Siyonizm'in oluştuğu atmosfer ortaya konulmaya çalışılacaktır. Üçüncü bölümde ise neo-Siyonizm’i mümkün kılan politikalar ve uygulamalar ele alınacak, iki yeni yaklaşım karşılaştırılmak suretiyle İsrail toplumu içerisindeki keskin ideolojik ayrışmaların yönü hakkında genel bir tablo ortaya konulacaktır.

\section{Bir İdeoloji ve Eylem Planı Olarak Siyonizm’in Ortaya Çıkışı}

Yahudi toplumsal kimliğinin spesifik bir şekli olan Siyonizm diğer milliyetçilikler gibidir. Bu açıdan ortak özellikler paylaşan bir grubun bir araya gelirken ve bir ülkü etrafında birleşirken tercih edeceği birçok ihtimalden sadece biridir (Kramer, 2008, s.103). Siyonist ideolojinin temel düsturlarından biri Yahudilerin bir ulus olduğudur. Bu husus milliyetçilik kuramları açısından tartışmaya açık olduğu gibi Yahudiliğin ayrıca bir dini inanç olarak görülmesinden dolayı da Yahudi(lik) olgusunu tanımlamayı ve sınıflandırmayı zorlaştırmaktadır.

Yahudiliğin bir ulus mu ya da din mi olduğu sorunsalı esasen modernleşme ile beraber gelen seküler ve geleneksel dindar yaşam biçimleri arasındaki gerginliğin de merkezindedir. Nitekim 
Yahudiliğin önce din olarak tanımlanması gerektiğini ileri sürenler açısından "Yahudileri yaratan Yahudi inancıdır, Museviliktir. Museviliği yaratan Yahudiler değildir. Önce Musevilik gelir. Musevilik bir ürün değil programdır ve Yahudiler bunun hayata geçirilmesinin araçlarıdır" (Rabkin, 2014, s.28). Bu bakış açısına sahip olanlar 19. yüzyılda ortaya çıkan ve modernleşmenin bir ürünü olan Siyonizm'i, normatif bir kavram olan Yahudiliği sadece betimleyici bir kavrama indirgediği ve bu suretle Yahudi kimliğini kökten değiştirdiği için kıyasıya eleştirir ve reddederler (Rabkin, 2014, s.29).

Her ne kadar Siyonizm temel argümanlarını Yahudi inancının kadim kavramları üzerine oturtmuş olsa da esasen seküler, dünyevi bir ideolojidir. Bu açıdan örneğin Fransız milliyetçiliğinden bir farkı yoktur. Siyonizm’in Yahudilerin bir ulus olduğu önermesinde başat bir rol oynadığına dair görüş milliyetçiliğin modernist yaklaşımında kendine yer bulur. Buna göre Siyonizm ortaya çıkmadan önce Yahudileri bir ulus olarak niteleyecek unsurlar yoktu; aynı toprak parçasında yaşamıyorlar, aynı dili konuşmuyorlar hatta ortak bir idare altında yaşama isteği barındırmıyorlardı (Berent, 2015, s.29). Bununla beraber Anthony Smith'in etno-sembolik yaklaşımı Yahudilerin bir ulus olduğu olgusunu Siyonizm’in ortaya çıkışından çok öncesine taşır. Smith modernleşmenin en azılı taraflarından biri olan Theodor Herzl'in dahi İsrail'i kadim diaspora Yahudileri için liman, asimile olmayı reddedenlerden oluşan bir Yahudi devleti olarak tasarladığını belirtir (Smith, 2017, s.6061 ). Böylesi bir devletin kurulacağı coğrafyayı son bağımsız Yahudi devleti olan Haşmonayim Krallığı’nın toprakları üzerinde (Johnson, 1988, s.107-111) yani Siyon'da tasarlaması ise Smith için ulus olgusunun kadim unsurlarla kesiştiği noktadır. Son tahlilde diaspora Yahudilerini Siyonist yapan ve onlara Filistin’e gitmek için ilham veren ve harekete geçiren dürtü modernleşmeden ziyade bu dini ve siyasi vizyondu. Smith'e göre Yahudileri ulus yapan ve Yahudi milliyetçiliğini ortaya çıkaran bu kadim şeceredir (Smith, 1996, s.377). Smith modern bir ideoloji olarak milliyetçiliği yadsımamakla beraber millet olgusunun sadece modernliğin bir ürünü olduğu varsayımına şerh düşer. Ona göre milletler etnik çekirdeklerden doğar. Milletler her zaman etnik unsurları gereksinirler. Bir toprakla fiziki ve fiili bir bağ kurabilmek için oraya dair ortak bir mit ve anılar olmaksızın milleti kavramak olanaksızdır (Smith, 2007, s.71). Her ne kadar kadim bir etnik topluluk olarak Yahudilerden bahsedilebilirse de Siyonizm Aydınlanma düşüncesi ve Fransız Devrimi’nin öğretileri ile şekillenmiş Avrupalı seküler Yahudilerce geliştirilmiş olan bir ideoloji ve eylem planıdır. Kadim etnik topluluk olan Yahudilerin dini inançları olarak nesillerce taşımış olduğu gelenekler ve ritüeller Musevilikten alınıp seküler ulusal sembollere taşınarak modernleşmiştir (Rabkin, 2014, s.89).

Siyonizm düşüncesinin ardında Yahudi karşıtlığı, antisemitizm yatmaktadır. Antisemitizm Avrupa tarihinde modern bir olgu değildir. Genel olarak Yahudi karşıtllğı antik dönemlerden itibaren Yahudilerin içinde yaşadığı toplumlarda var olmuştur. Bunda Hristiyanlığın etkilerinin de olduğunu söylemek mümkündür (Lazare, 1981, s.15-33). Bununla beraber Siyonizm’in liberalizme ve milliyetçiliğe verilen bir cevap olduğu da gözden kaçırılmaması gereken bir husustur. Zira Avineri (1981, s.13) önceki yüzyıllarda Yahudilere yapılmış olan zulümler ne kadar şiddetli olursa olsun, Siyonizm’in Fransız Devrimi’nden önce ortaya çıkmasının mümkün olmadığını öne sürer. Nitekim Hristiyanlıktan miras alınan Yahudi nefretinin 19. yüzylın düşünce hareketi olan milliyetçiliğin 
sosyal Darwincilik ile harmanlanması ırkçılığın yolunu açmış ve dolaylı olarak Yahudi karşıtlı̆̆ının beslenmesine neden olmuştur. Tarihsel süreç içinde geleneksel Hristiyan Yahudi nefreti önce Avrupa Aydınlanması içerisinde seküler bir düşmanlığa dönüşmüş sonra da ırkçı antisemitizme evrilmiştir (Shimoni, 1995, s.13). Yüzyılın sonuna yaklaşırken antisemitizmin geldiği nokta bu şartlar altında Avrupada yaşamanın imkânsız hale geldiği hususunda Yahudi düşünürleri ikna etmiştir (Levy, 2010, s.123). Aydınlanma düşüncesinin ve Fransız Devrimi’nin hediye ettiği bireycilik ve özgürlük gibi liberal düşüncelere rağmen söz konusu düşünürler Yahudilerin içinde yaşamakta olduğu toplumlarla bütünleşemeyeceğine, ayrımcllığa ve aşağılanmaya uğramaya devam edeceğine kanaat getirdiler. Bu durumun çözümü ise Yahudilerin hayatlarını idame ettireceği onlara ait bir anavatan kurmaktan geçmekteydi. Dolayısıyla Yahudi düşünürleri meseleyi milli ve siyasi açılardan ele almaya itmesinden ötürü Siyonizm’in milliyetçi bir ideoloji olarak ortaya çıkışında antisemitizmin ve ırkçılığın dolaylı bir katkısı olduğunu söylemek yanlış olmayacaktır. Hatta Rabkin daha da ileri giderek antisemitizm ile Siyonizm arasında üçönemli husus üzerinde bir oydaşma olduğunu öne sürer: Yahudiler dinsel bir grup değil ayrı bir ulustur; Yahudiler hiçbir zaman içinde bulundukları toplumla bütünleşmeyeceklerdir; Yahudi sorununun tek çözümü Yahudilerin gitmeleridir (Rabkin, 2014, s.136).

Klasik Siyonizm’i Doğu Avrupa'da baskı altındaki Yahudilerin problemlerine birtakım çözümler bulacak bir yerel hareketten ziyade tüm Yahudilerin tek bir ulus olarak özgürleşmesi hedefiyle (Halpern\&Reinharz, 1998, s.24) sorunun ancak Büyük Güçlerin müdahalesi ile çözüme kavuşacağından hareketle onu uluslararası bir sorun/konu haline getiren kişi Budapeşteli Yahudi gazeteci Theodor Herzl olmuştur (Shapira, 2012, s.17). Ancak ondan önce birçok Avrupalı Yahudi düşünür Yahudi halkının kurtuluşu için fikirler geliştirmiştir. Bu yüzden Avrupa'daki Yahudilerin durumundan endişe duyarak buna çözüm bulmak isteyen bazı düşünürlerin Siyonizm hareketinin temelini oluşturduklarını ve onu olgunlaştırdıklarını belirtmek gerekir. 19. yüzyılın ikinci yarısına gelindiğinde, 1850-1860 yılları arasında Yahudilerin Siyon’a (Filistin) dönmesi gerektiği fikri Yahudi entelektüeller arasında taraftar bulmaya başlamıștır. İlk olarak Polonya'da Rabbi Yehuda Alkalai (1798-1878) ve Rabbi Zvi Hirsch Kalischer (1795-1874) Kutsal Kitaba dayandırdıkları düşünceleri etrafında Siyon’a dönüşün tövbenin, kötü olandan vazgeçmenin, kefaretin ve yasaya uymanın bir gerekliliği olduğunu öne sürdüler. Mesihçi gelenek içinden yetişen dindar Yahudiler olarak, Alkalai ve Kalischer Orta ve Batı Avrupa ile Balkanlardaki özgürleşme ve asimilasyon hareketlerine reaksiyon gösterdiler. Bu düşünürlerin Siyon’a dönüş çağrısını şekillendiren Yahudilere yapılan zulümden ziyade onların Yahudi inancına ve kimliğine yabancılaşacakları korkusu olmuştur (Kramer, 2008, s.103). Her ne kadar Yahudilerin milli bir kurtuluştan ziyade ruhani kurtuluşu için endişelenmişlerse de teolojik unsurlar barındıran bu görüşü proto-siyonizm olarak adlandırmak mümkündür.

Yahudi sorununu esas olarak siyasi bakış açısıyla ele alan Almanyada yaşamış olan Moses Hess 1862 yılında yayınladığı Rom und Jerusalem (Roma ve Kudüs) adlı eseri ile Yahudi devletinin politik Rönesans'indan ve restorasyonundan bahsetmiştir. Alkalai ve Kalischer'den farklı olarak konunun öznesi olan Yahudileri bir dini cemaat olarak değil bir ulus olarak ele almıştır. Bu açıdan Moses Hess'i Siyonizm'in öncülerinden biri olarak nitelemek yanlış olmayacaktır. Hess kitabında bir Yahudi devleti kurulmasından söz etmiştir. Ona göre ancak Yahudilere ait olan bir devlette 
Yahudiler, Hristiyanlar tarafından yöneltilen batıl suçlamalardan münezzeh yaşayacaklar ve aynı zamanda Avrupa toplumlarına entegre olarak kimliklerinden taviz vermeden hayatlarına devam edeceklerdi (Johnson, 1988, s.375). Son olarak 1882 yılında yazdığı Autoemancipation (Özgürleşme) adlı eserinde antisemitizmin kalıtsal olduğunu öne süren bir Rus Yahudisi olan Leo Pinsker Yahudilerin kurtuluşunun Siyon’a dönmekten geçtiğini dile getirmiştir. Shimoni, Marx ve Engels'in Komünist Manifestosu sosyalizm için ne anlam ifade ediyorsa Pinsker'ın bu eserinin de Siyonist ideoloji için aynı önemi ifade ettiğini dile getirmenin abartı olmayacağını savunur (Shimoni, 1995, s.32). Ayrıca Pinsker'nn görüşlerinin Eretz Israel yönelimli bir milliyetçilik anlayışının ortaya çıkışını işaret ettiğini de söylemek mümkündür. Nitekim Pinsker Yahudilerin sorununun temelinde ulusal bir anayurtsuzluğun yattığını dile getirmiştir. Pinsker Rusya'dan Filistin’e ilk göçleri başlatacak olan Hovevei Zion (Siyon Aşıkları) adlı örgütlenmenin de lideri olarak göç hareketini (aliya) ilk körükleyenlerden biri olacaktır (Kramer, 2008, s.196). Theodor Herzl'in Siyonizm'i bir eylem planı olarak ortaya koymasından önce Pinsker dışında Nachman Krochmal ve Peretz Smolenskin gibi düşünürler de Yahudilerin bir millet olduğunu ve Filistin'de yerleşmeleri gerektiğini ilan ettiler ki böylesi bir çıkış kutsal topraklar yönelimli milliyetçi bir eylem planında kilit bir rol oynamıştır (Dieckhoff, 1993, s.30-48).

Fransa ordu mensubu Yahudi asıllı Yüzbaşı Alfred Dreyfus'un ihanetle suçlandığı duruşmayı (1894) (Selçuk, 2016) takip etmek için Paris’e geldiği sırada Herzl, bir grup Yahudi entelektüelin Yahudi sorununa çözüm için önerdiği asimilasyonun bir işe yaramadığı ve Yahudi halkı için bir şeyler yapmak gerektiği hususunda bir sonuca vardı. Ve Herzle göre tek çözüm Avrupa’yı terk etmek ve bir Yahudi devleti kurmaktı. Her ne kadar Siyonizm başlangıçta onun bu sorunu çözümlemek için bağlandığı bir hareket değildiyse de Herzl Siyonizm’in amaçlarını ve hedeflerini başarıya ulaştıran kişi olmuştur (Laqueur, 1972, s.88-95). Her ne kadar Pinsker'in eseri antisemitizmin daha derinlikli bir analizi olarak bir öncü eser olma özelliği teşkil etse de Herzl'in önemi bu fenomeni modern bir bağlama oturtmasında ve ondan somut sonuçlar çıkarmasında yatar. Gazeteci olarak Paris’te izlemiş olduğu ve neticesini haksız bulduğu Dreyfus davasından derinden etkilenmiş olmanın da etkisiyle Herzl modern antisemitizmin çok yönlü ve çok katmanlı olduğu sonucuna varmıştır. Herzle göre Yahudiler hem kapitalist hem devrimci; hem zengin hem fakir; hem eğitimli hem cahil oldukları için ayrıca yerel kültüre uyum sağladığ halde yine de ayrık kaldığı için nefret edilen bir topluluktu (Shapira, 2012, s.16). İronik bir biçimde Herzl Avrupa'daki antisemitizmin Avrupalı ülkelerin bir Yahudi devleti kurulmasına yardım etmesini sağlayacak bir itici güç olduğu sonucuna varmıştı.

Bu düşünceler ışı̆̆ında Theodor Herzl 1896 yılında Der Judenstaat (Yahudi Devleti) adlı kitabını yayınladı. Herzl bu kitapta Avrupadaki topluluklar içinde asimile olmak istemeyen Yahudilerin Filistin'de kurulacak bir devlete nakil sürecini, devletin karakterini, kurumların işleyişi gibi devlet olma sürecinde önemli olan her aşamayı ana hatları ile belirtti. Herzl'in kitabı İbranice, Rusça ve diğer pek çok dile çevrildi ve pek çok Yahudi tarafından bir program olarak benimsendi. $\mathrm{Bu}$ kitap özellikle II. Aliya (1904-1914) ile Filistin’e göçen sosyalist Yahudilerin rehberi olmuş, son tahlilde İsrail'in kuruluşu bu kitap üzerinde temellenmiştir. Herzl'i öncüllerinden farklı kılan ise kitapta dile getirdiği düşüncelerini bir eylem planına dönüştürmesi oldu. Kitabını yayınlandıktan 
bir yıl sonra 1897 yılında Siyonist Kongrelerin birincisini İsviçre’nin Basel şehrinde topladı, ilerleyen yıllarda Siyonist Kongreler Yahudi devletinin kuramsal temellerinin tartışıldığı, Siyonist ideolojinin konsolide olduğu platformlar haline gelecekti. Herzl'in bir diğer farkı ise sorunun Büyük Güçler vasıtasıyla çözümlenebileceğine inanması ve bu doğrultuda Yahudiler için bir anayurt belirlenmesi sürecinin bağlayıcı bir uluslararası belge ile desteklenmesi gerektiği yönündeki düşüncesidir. Herzl 1899 yllında 3. Siyonist Kongre'de görüşüldükten sonra Osmanlı Devleti ile görüşmeler yaparak bu doğrultuda çaba gösterdi (Khalidi, 1983). Ancak bir netice alamayınca Siyonist hareket bölgedeki çıkarları giderek artan ve I. Dünya Savaşı’nın ardından Filistin’de manda yönetimi kuracak olan Britanya ile yollarını birleștirdi; gerek Londra'daki hükümet ile gerekse de kolonilerden sorumlu bakanlarla kurduğu siyasi ilişkiler neticesinde hedeflerini gerçekleştirme yolunda adımlar attı. Gerçekten de Filistin'de bir Yahudi devletinin temellerini atan belge olarak tarihe geçmiş olan 1917 tarihli Balfour Bildirisi Siyonist Yahudilerin İngiltere'de yürütmüş oldukları diplomatik çabaların bir neticesidir (Schneer, 2015) ve uluslararası resmi bir belge olarak Yahudilerin Filistin’e yerleşmelerini kolaylaştırmıştır.

Herzl'in Yahudiler için idealize ettiği devletin Filistin'de kurulması gerektiği konusunda bir ssrarı olmadığını ifade etmek gerekir. Nitekim Siyonizm tarihi literatürüne "Uganda ihtilafı" olarak geçen tartışma göstermektedir ki, Herzl başlangıçta Filistin'de olmasa bile, problemin Yahudiler için büyük güçler tarafından verilecek bir toprak parçası ile çözülebileceğini düşünmekteydi. Herzl'in kurulacak bir Yahudi devleti için Yahudi inancına göre vaat edilmiş topraklar olan Filistin’i düşünmeksizin, tamamen seküler - milliyetçi bir düşünce biçimi ile herhangi bir toprak parçasını vatan olarak kabullenebileceği yargısının altında yatan neden onun Avrupa düşünce ve değer yargılarını benimsemiş ve aslında asimile olmuş bir Yahudi olmasından ve Siyonist projeye dini saiklerle bakmamasından kaynaklanmaktaydı (Finkelstein, 1987, s.15-56). Avineri de Siyonist hareketin kurucularının asimile olmuş Yahudiler olduklarını vurgulamıştır. Avineri'nin anlatısında bu kurucular "geleneksel, dindar bir geçmişten gelmiyordu. Hepsinin zihinleri Avrupalı entelektüel kesimlerin çağdaş fikirleriyle doluydu ve Avrupa eğitim sisteminin bir ürünüydüler. Vaatleri ne iktisadî ne de dinîydi. 1789 sonrası Avrupa kültürünün parçaları olan kendi kaderini tayin hakkı, kimlik ve özgürlük arayışındaydılar” (Avineri, 1981, s.14).

Buna rağmen Herzl 1896 yılında yayınladığı Yahudi Devleti başlıklı kitabında Yahudi sorununa tek çözümün Filistin'de bir devlet kurmaktan geçtiğini ilan etti. Şahsen Yahudiliğe yabancılaşmış ve bu konuda bilgisiz olan Herzl'in tutumu pragmatikti. Siyonizm karşıtı bir Yahudi olan Yakov Rabkine göre Herzl dinin kullanışlı olduğunu fark etmişti; siyasi düzeyde kilisenin Hristiyan topraklardaki etkinliğine benzer bir şekilde, Yahudiliği de devletin inşası için faydalı bir araç olarak gördü (Rabkin, 2014, s.73-4). Herzl'in bu eserde dile getirdiği düşüncelerden en önemlisi Filistin'de kurulacak olan devletin özellikle ve esasen Yahudi karaktere sahip olması gerektiğine yapmış olduğu vurgudur (Herzl, 1988, s.123-152). Nitekim bu düşünce tarzı İsrail devleti kurulduktan sonra orada yaşayan Filistinli nüfusa yönelik tavır ve tutumların belkemiğgini oluşturacaktı ve Filistinlilerin İsrail devletinin Yahudi karakterine bir tehdit olarak algılanmasına neden olacaktı. 
Son tahlilde Herzl'in girişimi ile Avrupa’daki Yahudi hareketinin resmî ideolojisi haline gelmiş olan Siyonizm'in amacı ve hedefi tarihi Siyon (Filistin) topraklarında yerleşerek orada Yahudi devletini tekrar kurmak olarak belirlendi. Siyonizm Avrupa’da yükselen rrkçllğ̆a ve Yahudi karşıtllğına, yine Avrupalı fikirlerin etkisiyle verilmiş milliyetçi bir cevaptı ancak ulusun yeniden canlandırılması vizyonun Filistin'de uygulanmaya karar verilmesinden sonra kolonyalist bir hareket halini aldı (Pappe, 2007, s.33). Siyonist ideolojiye yöneltilen bu eleştiri kimi İsrailli akademisyen ve gazetecinin nezdinde, İsrail kurulurken 1947 yllında Filistinlilere karşı yürütülen ve onların Filistin’den çıartılması ile neticelenen etnik temizlik ve 1967 yılındaki Altı Gün Savaşı ile gerçekleşen işgal ile doğrulanmış oldu. Bu kesimler yeni bir düşünce biçimi ortaya koydular. İsrail vatandaşı Filistinlilere yönelik ayrımcılı̆̆ın ve işgal altındaki topraklardaki Filistinlilere reva görülen zulmün eleştirisi etrafında şekillenen bu yeni yorumun adı post-Siyonizm oldu.

\section{Post-Siyonizm: Muhtelif Anlamları ve İsrail Toplumundaki Tezahürü}

1948 yllında kurulduktan sonra İsrail Arap ülkeleriyle bir dizi savaşa girdi (Ovendale, 2004, s. 177-227). Bu geçen süreç içerisinde hem devlet hem de toplum olarak İsrail’i dönüşüme uğratacak savaşlardan biri Haziran 1967 savaşı oldu. Mısır'la yapılmış olan bu altı günlük savaştan İsrail galip çıktı ancak hanesine bir sıfat daha eklendi: BM Taksim Planı ile Filistinlilere bırakılmış olan ve 1948 yılındaki Birinci Arap-İsrail savaşının akabinde Ürdün idaresi altında kalan Batı Şeria, Mısır idaresindeki Sina ile Gazze ve Golan Tepeleri İsrail ordusu tarafından işgal edildi. İsrail 1967 ylından sonra eleştirel kesimler tarafından işgalci bir devlet olarak nitelenmeye başladı. Bu savaş aynı zamanda İsrail'de post-Siyonizm’in ortaya çıkış sürecinin de başlangıcı oldu. Nitekim İsrail toplumu işgal altındaki toprakların elde tutulması ve barış yapılması karşıl lğında bu topraklardan çekilmesi gerektiği hususunda ikiye bölündü (Shlaim, 2000, s.228).

O güne kadar İsrail'in tüm savaşlarını bir varoluşsal tehdidi bertaraf etmek adına yürütülen savunma savaşı olarak gören kesim için 1967 yllından sonraki durum kabul edilebilir değildi. Bugüne kadar başka seçeneği olmadığı için savaşmak ve kendini korumak durumunda kalmış olan İsrail'in işgal ettiği yerlerden çekilmek ya da buralarda işgalci olarak kalmak arasında bir tercih yapması mümkündü çünkü Batı Şeria ve Gazze’yi işgal altında tutmaya devam etmek için görünürde hiçbir varoluşsal tehdit yoktu. Bir diğer kesim ise Mısır karşısında kaybedeceklerini düşündükleri bu savaşı bir mucize olarak görmeye başladı; Tanrı’nın vaat edilen toprakları onlara geri verdiği düşünülüyordu. Şüphesiz böylesi bir düşünce bu toprakların işgal altında olduğunu ve dolayısıyla İsrail'in işgalci bir devlet olduğunu reddedecek ve bu toprakların Filistinlilere iade edilmesine şiddetle karşı çıkacaktı.

Hem post-Siyonizm'in hem de neo-Siyonizm'in temelinde bu ayrışmanın olduğunu söylemek mümkündür. Tarihsel olarak ise önce post-Siyonizm'in ortaya çıktı̆̆ını söylemek yanlış olmayacaktır çünkü dönemin konjonktürü onu mümkün kılmıştır. Altı gün savaşı ile varoluşsal tehdit ortadan kalkınca Siyonist ethos zayıfladı, bu ethos etrafındaki kenetlenme de gevşedi, böylelikle post-Siyonizm bu süreçte kendine yer buldu (Gelber, 1999, s.5-10). Post-Siyonizm’i 
ortaya çıkaran konjonktürün izlerini 1979 yılındaki Mısır-İsrail barış anlaşmasına götürmek mümkündür. 1978 yılındaki Camp David Anlaşması ve 1979 yılında imzalanan barış antlaşması iki ülke liderinin Amerikan başkanı aracılığında el sıkışması ve İsrail'in Sina'dan çekilmesi şartıyla imzalanmıştır. Bu anlaşma İsrail'in Ortadoğu'da Arap ülkeleri ile savaşmadan varlığını sürdürebileceği yönündeki umutları beslemiştir. 1993 yılında Filistinlileri temsilen Filistin Kurtuluş Örgütü ile yapılan anlaşma neticesinde başlayan Oslo Süreci de barışçll ve umutlu atmosferin oluşmasında katalizör görevi görmüştür.

Post-Siyonizm’in bir karşı-hegemonik söylem olarak tezahürlerine ilk önce akademide rastland1. Yahudi devletinde tabu olan konular tartışmaya açıldı: sömürgecilik olarak Siyonizm, Nekbe, İsrail'in Filistinli vatandaşlarına yapılan ayrımcılık, soykırımın manipüle edilmesi gibi (Pappe, 2014, s.127). Bu konuları eleştirel bir şekilde ele alan tarihçilere 'yeni tarihçiler' denmeye başlandı (Greilsammer, 2012). 1948 yılının arşivlerinin de araştırmacılara açılmasıyla beraber o güne değin hâkim olan ulusal anlatıların da eksik ya da hatalı olduğu bu araştırmacılar tarafından ortaya konmuş oldu. Bu bağlamda yazılan tüm eserlerin post-Siyonist olarak nitelenmesi doğru olacaktır; nitekim bu eserlerin yazarları Siyonist tarih yazımını ve Siyonizm’in ideolojik varsayımlarını tartışmaya açtılar. Yeni tarihçi olarak nitelenen yazarların hepsi kendilerini postSiyonist olarak nitelemese de ortaya koydukları eserlerin post-Siyonist literatürü ortaya çıkardı̆̆ı bir gerçektir. Buna Simha Flapan'ın 1987 yılında yayınlamış olduğu The Birth of Israel: Myths and Realities başlıklı araştırması iyi bir örnektir. Flapan (1987) bu eserde, gizliliği kaldırılan arşiv belgelerinden yola çıkarak İsrail'in kuruluşunda öne sürülen yedi ulusal anlatının ne kadarının propaganda ne kadarının gerçek olduğunu tartışmıştı. Sadece yeni tarihçiler değil sosyologlar da bu literatürün oluşmasına katkıda bulunmuşlardır (Waxman, 1997). Akademide başlayan bu düşünce dönüşümü kamusal alanda da kendini gösterdi. Geçmiş hakkında yeni söyleşiler ve röportajlar, radyo ve televizyonlardaki sohbet programlarının ilgi çeken konusu haline geldi. Askerler ve o dönem resmi hizmette bulunmuş olanlar 1948'in yeni tarihi ve 1950'li y1llarda İsrail'in politikaları gibi konularda yapılan tartışmalara davet edildiler (Pappe, 2014, s.128).

Bu yeni düşünce biçimi ve dönüşüm post-Siyonizm olarak nitelendi ancak bugün post-Siyonizm'in tek bir tanımını yapmak zordur. Yine de akademisyenlerin araştırmalarına yansıyan unsurlardan genel geçer bir tanım yapmak mümkün olmuştur. Kelman post-Siyonizm’i hem betimleyici hem de normatif olarak ele alır. Buna göre post-Siyonizm İsrail'de tedrici bir şekilde sürmekte olan ideolojik değişime işaret eder ve bu değişim İsrail’in Yahudi nüfusu açısından nasıl görüldügüne ilişkindir. Dışlayıcılıktan çoğulculuğa, Filistinliler üzerinde tahakküm kurmaktan eşitliğe ve ortaklığa, izolasyonizmden ve düşmanlıktan komşularla iyi ilişkiler kurup bölgeye entegre olan bir İsrail’e doğru bir dönüşüm post-Siyonist söylemi oluşturur (Kelman, 1998, s.47). Silberstein (1999, s.2) post-Siyonizm'in tıpkı Siyonizm gibi farklı yaklaşımları içinde barındırdı̆̆ını belirtir; buna göre post-Siyonizm Siyonist söylemin, tarihsel anlatılarına ve onun ürettiği sosyo-kültürel temsillere karşı takınılan eleştirel tavırlar ve tutumlar bütünüdür. Ram (2005a, s.26) ise postSiyonizm'i Yahudi ulusal hareketi olarak Siyonizm’in meşruiyetini kabul eden bir ekol olarak nitelemiştir. Ancak ona göre Siyonizm diğerlerine yaptı̆̆ 1 hatalardan (Filistinliler, Sefaradlar, kadınlar, Ortodoks Yahudiler, Falaşalar olarak da bilinen Etiyopyalı Yahudiler) dolayı meşru 
zeminini kaybetmiş, tarihi rolünü sonlandırmıştır. Bu yüzden İsrail artık Siyonist bileşenlerini bırakmalıdır çünkü bu bileşenler onu demokratik bir devlet olmaktan alıkoymaktadır.

Görüldügü üzere post-Siyonizm klasik Siyonizm’in tarihi rolüne ve fikirlerine karşı gelmemekle beraber onun temel düsturlarına karşı yeni bir anlayış geliştirmeye çalışan bir yaklaşımdır zira post-Siyonizme göre Siyonizm artık miadını doldurmuştur çünkü başlıca hedeflerini yerine getirmiştir. Dili İbranice olan, nüfusunun çoğunluğu Yahudilerden oluşan, gelişmiş bir ekonomisi olan ve kendini savunabilen bir Yahudi devleti kurulmuştur. Bu yüzden artık İsrail Siyonizm'i ve onu fikirlerini geride bırakmalı, yeni bir fikirsel döneme girmeli, normalleşmelidir (Ben-Moshe, 2004, s.314). Siyonizm’in doğası gereği sömürgeci ve uygulamada ırkçı olduğunu öne sürerek Yahudi milliyetçiliği olarak Siyonizm’i reddeden anti-Siyonistleri de post-Siyonist çerçeve içine koymak mümkündür. Buna göre Siyonizm’in temel prensipleri, herkesin eşit olarak yaşayacağı demokratik bir devlet kurulmasını engellemiş̧ir. İsrail kendisini Yahudi devleti olarak nitelediği müddetçe eşitlik sağlanamayacaktır. Böylesi bir yaklaşımın gelişmesinde İsrail'in Filistinli vatandaşlarının uğradığı eşitsizlik ve ayrımclık yatmaktadır. Nitekim İsrail'de Filistinli vatandaşların devletin hemen her kademesinde ayrımcı/dışlayıcı tutumlara maruz kaldığı, bu tutumun İsrail'de kurumsallaştığı bir vakıadır (Rouhana, 1997). Siyonist ülkünün tezahürleri olan Geri Dönüş Yasası ile Yahudi Milli Fonu ve Yahudi Ajansı gibi kurumlar sadece Yahudi vatandaşlar için politika geliştirmekte ancak bunu yaparken Filistinlilerin aleyhine tavır takınmış olmaktadır. Bu durumun çözümü için, diğer bir deyişle İsrail'de Filistinlilerin de Yahudilerle eşit muamele görmesi için İsrail'in normalleşmesi, Ortadoğu'ya tamamen entegre olması ve tüm vatandaşların eşitçe yaşayacağı liberal-demokratik bir devlet haline gelmesi gerekmektedir (BenMoshe, 2014, s.315-9).

Post-Siyonizm'in bu 'negatif' argümanları İsrail'deki muhafazakâr kesimin varoluşsal tehdit algısını yükseltmektedir ve bu kesimlerin post-Siyonizm'in yapıcı eleştirilerine kulak tıkamasına neden olmaktadır. Hâlbuki post-Siyonizm bu argümanları ile ele alındığında dahi devlet Yahudi karakterini kaybetmeyecektir. Post-Siyonist bir İsrail'de İbranice, konuşulan dillerden biri olacak, Yahudi kültürü ve tarihsel belleği var olmaya devam edecektir. Bununla beraber devletin başat rolü sadece Yahudi vatandaşlarını ve onların çıkarını değil tüm vatandaşlarını ve çıkarlarını korumak olacaktır. Etnik aidiyete bağlı olmaksızın yurttaş haklarından herkesin faydalandığı çoğulcu bir demokrasi olacaktır. Devletin eğitim ve sağlık gibi başlıca imkânlarından tüm vatandaşlar eşit bir şekilde yararlanacaktır (Kelman, 1998, s.50-1).

Bugünden bakıldığında 1990 'lı yılların barış ve umut vaat eden ortamında yeşermiş olan bu fikirlerin İsrail'de geniş kesimlerce benimsenmesi halen bir ütopyadan ibarettir. Her şeyden önce İsrail toplumu kendi içinde derin kimliksel ayrışmalarla bölünmüş durumdadır. Yahudi ve Filistinli (Arap) olan etnik ayrışmanın dışında Yahudiler Sefarad-Aşkenazi, dindar-seküler ve Beta İsrail olarak bilinen Etiyopyalı Yahudiler olarak kendi içinde de çok katmanlı bir şekilde bölünmüştür Bu sosyo-ekonomik bölünmeler sınıfsal bir çatışma olarak kendini göstermektedir. Her grubun devletten farklı beklentisinin olduğu böylesi bir yapının yukarıda değinilen çoğulcu ve eşitlikçi ideal etrafında birleşmesi oldukça zordur. Hatta post-Siyonist bir dönüşüm dindar 
muhalefet tarafından engellenmektedir. İsrail'de kulturkampfin dindar ve seküler gruplar arasında sürdügünü söylemek yanlış olmayacaktır (Ersoy, 2018, s.93). İsrail’de dindar sektör iktidara gelmek ve koalisyon kurabilmek için liderlerin bağımlı olduğu bir sektördür. Bu yüzden dindar kesimin gücünün sınırlandığ ve iki grup arasında bir denge kurulduğu takdirde post-Siyonist bir dönüşüm için ilk adım atılmış olacaktır.

Son tahlilde post-Siyonizm'i İsrail'de dışlayıclıktan çoğulculuğa, tahakkümden eşitliğe ve yalnızlıktan bölgesel bütünleşmeye doğru yönelmiş bir ideolojik değişim, yeni bir siyasi kültür olarak tanımlamak mümkündür. Ne var ki 1993 yılında Oslo süreci ile hâsıl olan barış̧̧ıl ve umutlu atmosfer 2000 yılında barış sürecinin çökmesini takiben başlayan el-Aksa İntifadası ile yok olmuştur. Yeniden şiddetle tanışan bu topraklarda taraflar arasındaki düşmanlık hissi pekişirken, post-Siyonist idealin de o atmosfere ait bir haleti ruhiye olduğu tescillenmiş oldu. $\mathrm{O}$ iyimser havanın ortadan kalkmasıyla da her ne kadar halen ufak bir kesim tarafindan benimseniyor olsa da kitleleri peşine takacak bir fikir olarak post-Siyonizm’in öldüğünü söylemek mümkündür (Pappe, 2014, s.132).

Öte yandan post-Siyonizm'in güçlü karşıtları da vardı. Bunlardan ilki ana akım liberal Siyonizm'di. Liberal Siyonizm İsrail'i Yahudi ve demokratik bir devlet olarak tanımlarken, post-Siyonizm bu nitelemenin bir tezat (oxymoron) olduğunu ve İsrail'in Yahudi devleti olarak betimlenmesinin onu etnik bir devlet yaptığını öne sürmüştür. Post-Siyonizm’in ezeli düşmanı ise neo-Siyonizm olmuştur. Bu iki ekolün bugün İsrail siyasi kültüründe iki karşıt ucu temsil ettiğini söylemek yanlış olmayacaktır. Post-Siyonizm ile neo-Siyonizm arasındaki karşıtlık tabiri caizse bir medeniyetler savaşıdır: evrensel, kozmopolit ve özgürlükçü post-Siyonist taraf ile şovenist ve tikelci, ırkçı neoSiyonist taraf arasında geçen bir savaş (Ram, 2005a, s.35-6).

\section{Neo-Siyonizm'in Ortaya Çıkışı ve Zaferi}

Sağcı ve etnik milliyetçi-dindar bir ideoloji olarak neo-Siyonizm post-Siyonizm'den daha eski bir düşünce biçimidir ancak İsrail toplumu içerisinde taraftar bulmaya başlaması ve bir fenomen haline gelmesi $1990^{\prime} l ı$ yılların sonuna denk gelir. Bu yüzden de post-Siyonizm’e bir tepki olarak popüler hale geldiğini öne sürmek mümkün olmuştur.

Etnik milliyetçi ve dindar bir sağ kanat ideolojisi olarak neo-Siyonizm 1967 yllında gerçekleşen Altı Gün Savaşı̀nda İsrail'in Kudüs, Batı Şeria ve Gazze’yi işgal etmesinin akabinde Yahudilerin bu bölgelerde yaşayan Filistinlilerle etkileşime girmesi neticesinde oluşmaya başlamış bir siyasi tutumdur. 1967 yllında kazanılan zaferin 'şoku' yaşananlara anlam vermeye çalışan bir dizi düşünce akımları ortaya çıkardı. Bu düşünce akımları gelecek yıllarda İsrail toplumunu ve siyasetini şekillendirecekti (Einav, 2018, s.262). Ayrıca bu işgaller siyasi ideolojiye dini boyut kazandırdı. İsrail'in Arap orduları karşısında hezimete uğrayacağını düşünen bir kesim, savaş sonrasında Kitab-1 Mukaddes’te Yahudi krallığına ait olduğu anlatılan bu toprakların ele geçirilmesini bir mucize olarak betimledi. Kitab-1 Mukaddes'te Yahudiye ve Samiriye olarak geçen Batı Şeria artık İsrail'de kalmalı ve buralara Yahudiler yerleşmeliydi. İște bu anlatı neo-Siyonist ideolojinin dini 
arka planını oluşturmaktadır. Yeşil Hattın gerisinde, yani İsrail'de yaşamakta olan Filistinlilerin de buralardan çıkarılmasına yönelik politika ise bu ideolojinin etnik-milliyetçi çerçevesini teşkil eder.

1990’lı ylllarda İsrail siyasi kültüründe sol kanat, evrensel ve plüralist post-Siyonizm’in karşıt kutbu olan bir ideolojik tutum olarak popüler olmadan önce neo-Siyonizm'in ideolojik bir kanat olarak siyaset sahnesine çıkışını önceleyen oluşumlar vardır. Büyük İsrail Hareketi (Eretz Yisrael HaŞleima) ve İnanalar Bloğu (Gush Emunim) adlı yerleşimci hareketi bugün İsrail toplumunun bir kesimini temsil eden neo-Siyonist ideolojinin temellerini teşkil eder.

Büyük İsrail Hareketi 1967 savaşından bir ay sonra kuruldu. Yazar Nathan Alterman Maariv gazetesinde yayınladığı bir makalesinde ele geçirilen topraklara yönelik tek eksiğin o topraklarda din adamlarının bulunmaması olduğunu çünkü İsrail toprakları ile Yahudi halkının arasındaki bağın derinliğini ancak onların sembolize ettiğini dile getirdi. Bu çağrının akabinde bir grup siyasetçi, yazar ve şair bir araya gelerek toplantılar yapmaya başladılar (Uriel, 2014, s.90-1). $\mathrm{Bu}$ toplantıların sonunda vücut bulan hareketin kuruluş belgesinde İsrail hükümetine işgal ettiği toprakları Yahudilerin yerleşimine açması ve elinde tutması çağrısında bulunuldu. $\mathrm{Bu}$ topraklarda yerleşmenin önemi sadece güvenlik gerekçeleriyle açıklanamazdı; toprakların bütünlüğü İsrail halkının ruhunu ve özünü güçlendirecekti (Uriel, 2014, s.92). Belgede ayrıca İsrail'deki hiçbir hükümetin bahsedilen bu bütünlügü, ele geçirilen toprakları bırakarak, bozmaya hakkı olmadığına vurgu yapılmıştı (Uriel, 2014, s.96). Bu kararlılık bugün İsrail siyasetinde yerleşimcileri temsil eden dindar partilerin önemini gözler önüne serer. Büyük İsrail Hareketi’nin ideolojisi oldukça radikaldi. 1967 yılında ele geçirilen toprakların İsrail’e bağlanması, barış anlaşması için koz olarak kullanılmaması çağrısının yanı sıra (Shlaim, 2000, s.286) İsrail'in 'tarihi' topraklarında genişlemesi gerektiğini savunuyordu. Bu topraklar Ürdün'ü içine alarak kuzeyde Suriyedeki el-Hama'dan güneyde Nile kadar ve Firat nehrinden Akdenize kadar olan tüm toprakları kapsamaktaydı (Encyclopedia of the Middle East). Büyük İsrail Hareketi güvenlik, İsrail devletinin gücü, devletin Filistinlilere yönelik tavrı ve etik gibi aynı zamanda Filistin-İsrail çatışmasının, sınır sorununun, mülteci sorunu ve Kudüs meselesinin de temelinde bulunan konularda hem kamuoyunun hem de devletin siyasi söyleminin değişmesinde katalizör görevi gördü (Einav, 2018, s.267).

Daha önce değinildiği üzere Haziran 1967 savaşının yaşandığg yıllarda da İsrail'in kuruluşu ile Siyonizm’in miadını doldurduğu tartışmaları gündemdeydi. Büyük İsrail Hareketi’nin kurucularından biri olan Avraham Yaffe'ye göre ise yolun sonu henüz gelmemişti çünkü henüz devlet içindeki problemler çözüme kavuşmamıştı. İsrail, İşçi hareketi tarafından kurulmuştu ve Yaffe'ye göre bundan sonra Gush Emunim yeni öncü olacaktı (Uriel, 2014, s.99).

Gush Emunim İsrail siyasi tarihinde bir başka dönüm noktası olan ve resmi tarihte deprem olarak nitelenen Ekim 1973 (Yom Kippur) savaşından sonraki süreçte bir fenomen olarak ortaya çlkmıştır. 1974 yılında resmi olarak kurulan; etnik ayrilıkçı ve irredantist olarak nitelenebilecek bu hareketin büyümesini mümkün kılan ise sağ kanat bir parti olan Likud’un ilk defa İşçi partisine karşı zafer kazandığı 1977 seçimlerinin yaratmış olduğu siyasi atmosfer olmuştur (Avruch, 1979, 
s.49). Bu netice bir bakıma 1967 yılında Gazze ve Batı Şeria’nın işgal edilmesinden sonra bu topraklarla ne yapılacağı konusunda ikiye bölünen İsrail kamuoyunun ve siyasetinin bir tezahürü idi. Barış karşılığında toprakların geri verilmesini savunan ve o topraklar üzerinde kurulacak bir Filistin devleti bağlamında iki devletli çözümü destekleyen liberaller ile o coğrafyanın Tanrı tarafından Yahudilere vaat edildiğini ve asla başka halklara bırakılmaması gerektiğini savunan ve Filistinlilerin İsrail işgali altındaki topraklardan çıkarılmasını talep eden etnik-dini milliyetçiler iki karşıt kampı oluşturdular (Shlaim, 2000, s.287). İşte Gush Emunim hareketi de böylesi bir konjonktürde işgal altındaki topraklarda mümkün olduğunca fazla sayıda Yahudi’nin yerleşmesini bir siyasi tavır ve ajanda olarak belirlemiş olan Likud hükümetinin desteği ile popüler hale geldi. Bu noktada Gush Emunim'in İsrail siyasi kültüründeki önemli değişimlerin sadece bir neticesi değil aynı zamanda bu değişimlere şekil veren aktif bir aktör olduğunu öne sürmek mümkündür (Aronoff, 1988, s. 307).

Gush Emunim liderleri ve aktivistleri İsrail'de 1953 yılında kurumsallaşmış olan örgün eğitimden özerk bir biçimde işleyen bir dini eğitim sistemine ait kurumlardan mezun olmuş kişilerdi. Gush Emunim kurucularının hepsi Yeșivat Merkaz Harav adlı okuldan mezun oldular ve Rabbi Abraham Isaac Kook'un oğlu Rabbi Zvi Yehuda Kook’un öğrencileriydiler (Aronoff, 1988, s.3156). Hareket, düşünsel ideolojik temelini Rabbi Isaac Kook’un öğretilerinden ve bu öğretilerin oğlu tarafından genişletildiği ve yorumlandığı güncel versiyonundan devşirdi. Buna göre tarihi Eretz Israel ve Yahudi halkı bir bütündür. Kutsal topraklar Yahudiye ve Samiriye mucizevi bir biçimde kurtarılmıștır ve atalardan miras kalan bu topraklara yeniden sahip olmak ve üzerinde yaşamak her Yahudi’nin kutsal görevidir (Aronoff, 1988, s.318). Bu görev kutsal addedildiği için, ona yönelik herhangi bir muhalefete de hoşgörü gösterilemez. Hatta Rabbi Kook Yahudilerin yerleşimler aracılığıyla ödediği kefaretin aynı zamanda halkın siyasi çıkarına olduğunu ve halkın çıkarını temsil etmeyen hükümetin de meşru olamayacağını öne sürmüştür. Bu yüzden Rabbi Kook'un ve dolayısıyla Gush Emunim'in dünya görüşünde İsrail’in işgal altındaki topraklardan çekilmesini talep eden her kimse ve buna boyun eğen her hükümet Tanrı tarafından lanetlenecektir (Weissbrod, 1982, s.269). Dönemin başbakanı olan Ariel Şaron’un 2005 yılında Gazze'den tek taraflı olarak çekilme kararı alması ve bunu eyleme dönüştürmesi sırasında yaşanan karışıklıklar ve öfkeli tepki hatırlandığında bu söylemlerin sadece retorikten ibaret olmadığı ortaya çıkmaktadır.

Görüldüğü üzere hareket Yahudilerin toprakla olan mistik bağını Siyonist ideolojide merkezi bir role sahip olan Filistin topraklarında yerleşme ülküsü ile ilişkilendirmektedir. Büyük İsrail Hareketi lideri Avraham Yaffe’nin de inanmıș olduğu gibi Gush Emunim üyeleri kendilerinin özellikle II. Aliya sürecinde Filistin’e gelerek Siyonist yerleşimi başlatan öncülerin gerçek halefleri olduklarına iddia etmektedirler. Böylelikle Gush Emunim kendini miadını doldurduğu düşünülen klasik Siyonizm’i canlandırma misyonu da yüklenmiş olan bir yeniden doğuş hareketi olarak konumlandırmıştır. Bununla beraber Gush Emunim’in köklerinin Siyonist ideolojinin 'dini' ve 'seküler' şeklinde farklılaşmasında bulunduğunu söylemek mümkündür. Ancak 1974 yılında bu hareketi mümkün kılanın da hem dini hem de seküler unsurları bünyesinde toplayarak 19. yüzyılda sürgüne son verme amacı ile vücuda gelen aynı Siyonist ideoloji olduğunu 
unutmamak gereklidir (Avruch, 1979, s.50). Klasik Siyonizm gibi Gush Emunim’in benimsediği dini Siyonizm’in de destek bulmasının ve bir anlamda başarılı olmasının ardındaki neden ise Yahudi kimliğinde merkezi önemde olan değerler sistemine dokunmuş olmasıdır (Weissbrod, 1982, s.271).

Gush Emunim anlaşılacağı üzere dini boyutu olan bir hareket olmakla beraber bu grup bünyesinde seküler dünya görüşüne sahip Yahudileri de barındırmaktaydı. Bunun sebebi ultra-milliyetçi Siyonist bir hareket olarak nitelenecek Büyük İsrail Hareketini oluşturan yazar, entelektüel ve generallerden oluşan elit bir grubun zamanla Gush Emunim içine çekilmiş olmasıdır. Bundan daha da önemlisi iki hareket Eretz Israel anlayışını benimsemiş ve toprağa kozmik anlamlar yüklemiş olduğu için dindar-seküler çatışmasını ortak ülkü etrafında birleşerek aşmıştır (Çağlayan, 2004, s.408).

Bugün İsrail toplumunun kayda değer bir kısmının benimsediği neo-Siyonist ideolojinin tarihi ve ideolojik arka planını Büyük İsrail Hareketi ve Gush Emunim yerleşimci hareketinde bulmak mümkündür. Hatta Ehud Sprinzak’n belirttiği üzere bu iki erken oluşum da İsrail toplumuna paraşütle inmemiştir; uzun yıllar boyunca sessizce büyüyen bir sosyal ve kültürel yapının savaşlar gibi çeşitli koşullarla şekillendirdiği buzdağının aşırı uçtaki parçasıdır (Spinzak, 1981, s.28-47).

Kökleri 1990'lı yllardan önceye dayansa da kavram olarak neo-Siyonizm post-Siyonizm'in karşıtı olan bir siyasi tutumu betimlemek için kullanılmış yeni bir kavramdır. Diğer bir deyişle Haziran 1967 savaşından sonra İsrail'de gelişmeye başlayan yukarıda değinilen hareketler nezdinde sesi duyulan siyasi ve dini ideolojinin genel bir adıdır. Uri Ram (2002, s.57) sol kanat post-Siyonist ideoloji ile paralel bir şekilde ve ona muhalefet olarak gelişen bu fenomeni dışlayıc1, milliyetçi, ırkçı ve anti-demokratik siyasi-kültürel bir eğilim olarak tanımlamıştır

Neo-Siyonizm, bir Yahudi devleti kurarak burada tüm Yahudileri bir araya getirme projesi olan Siyonizm’in artık görevini tamamladığını savunan post-Siyonist ideolojiye doğrudan saldırır ve kendisini Siyonist ruhun yenilenmiş biçimi olarak selamlar. Tarihi Eretz Israel toprakları neo-Siyonist proje tarafından birleştirilecektir. Bu noktada Ramıın tanımlamasına dindar betimlemesini de eklemek elzemdir. Neo-Siyonist ideoloji ırkçı ve etnik milliyetçi olduğu kadar, dini öğretileri de benimseyen bir siyasi tutumdur. Nitekim işgal altındaki topraklarda yerleşimlerin çoğalması ve buralardan Filistinlilerin çıkartılmasına dönük siyasi söylem Kitab-1 Mukkaddes'teki ayetlere referansla desteklenmektedir. Şu ayet neo-Siyonist ideolojinin temel anlayışını adeta özetler niteliktedir:

"Size yeni bir yürek verecek, içinize yeni bir ruh koyacağım. İçinizdeki taştan yüreği çıkaracak, size etten bir yürek vereceğim. Ruhumu içinize koyacağım; kurallarımı izlemenizi, buyruklarıma uyup onları uygulamanızı sağlayacağım. Atalarınıza verdiğim ülkede yaşayacak, benim halkım olacaksınız, ben de sizin Tanrınız olacağım." (Hezekiel 36:26-28)

Görüldüğü üzere Tanrı’nın vereceği yeni yüreğin taşıyıclları neo-Siyonistlerdir. Bu ideolojiyi benimseyenler Tanrının buyruklarına göre hareket edecekler, diğer bir ifadeyle Tanrının 
sözünden çımmayacaklar ve onlara vaat edilmiş olan topraklarda yaşayacaklardır. NeoSiyonizm'de bu vaat siyasi olmaktan öte ruhani/ilahi bir anlam yüklenmiştir. Neo-Siyonist ajanda tüm Filistin topraklarında İsrail'in hâkim olunmasıyla beraber M.S. 70 yılında Roma tarafından yıkılan tapınağın yeniden inşasını da hedeflemiştir. Dayanağını yine Kitab-ı Mukkaddes'ten alan bu söylem her hafta Şabbat ayininde ifadesini bulur: "Tapınak yeniden inşa edilecek, Siyon şehri dolacak. Ve biz orada yeni bir şarkı söyleyecek, neşeyle ayağa kalkacağız." Hem işgal altındaki topraklarda yerleşme planı hem de şu an yerinde Müslümanlar için kutsal bir yer olan Harem-i Şerif'in bulunduğu yerde Kudüs Tapınağı'nı yeniden inşa etme hedefi kaçınılmaz olarak Filistinlileri neo-Siyonizm’in düşmanı haline getirmektedir. O yüzden neo-Siyonist ideoloji Filistinlilerle anlaşma yapmaya, onların işgal altındaki topraklarda başkenti Doğu Kudüs olacak bir devlet kurmasına ve Filistinli mültecilerin geri dönüşüne şiddetle karşı çıkmaktadır. Bu etnikmilliyetçi, ırkçı ve dogmatik haliyle neo-Siyonist ajandaya veya söyleme meydan okuyan herhangi bir yorum ve tutum vatana ihanet olarak nitelendirilmektedir (Pappe, 2014, s.249).

Neo-Siyonizm'i muzaffer kılan atmosfer aynı zamanda post-Siyonizm'in yenilgisinin de tescillendiği atmosferdir. 1990'lı yılların sonunda Batı Şeria ve Gazze halen işgal altındaydı, büyük umutlarla başlayan Oslo süreci donmuş durumdaydı, İsrail'de ikinci sınıf vatandaş muamelesi gören yoksul gruplar hak talep etmekteydi ve bu durum İsrail toplumunu bir kimlik krizi içine çekmişti. Böylesi bir noktada ya daha liberal, kapsayıcı ve çoğulcu siyasi bir tutum galip gelecekti ya da saldırgan bir politika benimsenecekti. Bu ikinciye yönelik süreç 1977 seçimleriyle başlamıştı. 1982 Lübnan Savaşı, 1987 yılındaki I. İntifada, barış sürecini tamamen rafa kaldıran Izak Rabin suikastı ve 1996 yılında Likud’un Benjamin Netanyahu başbakanlığında iktidara gelmesi neoSiyonizm'in zaferini, post-Siyonizm'in ise yenilgisini simgeledi (Shlaim, 2000, s. 565-75).

Post-Siyonist bakış açısı 1999 yılında kadar sürse de Oslo sürecinin çökmesi ve Rabin suikastı toplumdaki iyimserliğin kaybolmasına, Filistinlilere karşı güvensizliğin artmasına, son tahlilde kötümserliğe neden oldu ve siyaseten de sağ kanada doğru bir eğilimle neticelendi. Yeni tarihçiler ve onların yazdıkları vatana ihanet olarak yorumlanmaya başladı ve post-Siyonizm'in nihai ölümü Eylül 2000'de patlak veren II. İntifada ile gerçekleşti. 2001 yılında sağ kanat Kadima partisinden Ariel Şaron'un oyların çoğunluğunu alarak iktidara geldiği yıl, uluslararası konjonktürün 11 Eylül saldırılarıyla kaos içine girdiği ve hemen akabinde terör örgütlerine yönelik teröre karşı küresel savaşın başlatıldığı yeni bir siyasi bağlama denk geldi. II. İntiafada sürecinde Filistin terörizminden dem vuran sağcı, ayrılıkçı İsrailli siyasetçiler açısından bu konjonktür kamuoyunu arkasına alma hususunda büyük yarar sağladı. Böylece neo-Siyonizm hem toplumda hem de siyasette karşılığını bulmuş oldu.

Pappe neo-Siyonizm'in yükselişini sağlayan dört paralel süreçten dem vurur. Buna göre müstahkem mevkileri yerleşimler ve devlet destekli yeşivalar olan dindar-milliyetçi grupların radikalleşmesi; daha önce anti-Siyonist olan ultra-Ortodoks Yahudilerin (Haredim) Siyonist ideolojiyi benimser hale gelmesi; Mizrahi Yahudilerin (Doğu Yahudileri) toplumun gerek coğrafi gerekse de toplumsal sınırlarına itilerek etnik olarak tecrit edilmesi ve son olarak İsrail'in kapitalist globalleşme sürecine hızla dâhil olması ve bunun neticesinde ABD'deki Yeni Sağ’ 
andıran yeni-muhafazakâr oluşumların ortaya çıkması neo-Siyonist ideoloji ve siyasetin hâkim hale gelmesinde katkısı olan gelişmelerdir (Pappe, 2014, s.265).

\section{Sonuç}

İsrail'de özellikle Haziran 1967 savaşının akabinde iki farklı kimlik kutbu belirmiş; bu farklı kimlik gruplarının siyasi ve ideolojik tutumu evrensel ve çoğulcu post-Siyonizm ile yerel, dışakapalı neo-Siyonizm yaklaşımlarında somutlaşmıştır. Bu yaklaşımların bir kimlik kutbu olarak pekişmesinden sonra İsrail'de üç farklı siyasi kültürü betimleyen üç Siyonizm yorumu ortaya çıkmıştır:

Klasik Siyonizm siyasi ajandasını Yahudi ve demokratik bir İsrail söylemi üzerinden gerçekleştirmeye odaklanmıştır. Post-Siyonizm ise kozmopolitan ve liberal bir bakış açısı benimseyerek ülkede yaşayan herkesin eşit haklara sahip eşit vatandaşlar olarak kabul edildiği bir devlet tasavvur etmiştir. Buna karşın neo-Siyonizm etnik-dini milliyetçi bir eğilim benimseyerek Yahudiler dışında kalan tüm grupların dışlandığı ırkçı ve ayrımcı bir siyasi kimlik ortaya çıkarmıştır (Ram, 2005b, s.26). Post-Siyonizm açısından İsrail sınırları uluslararası olarak tanınmış egemen bir devletken, neo-Siyonizm için İsrail Kitab-ı Mukaddeste bahsedilen kutsal topraklardır. Post-Siyonizm için otorite vatandaşları temsil eden demokratik kurumlarken, neoSiyonizm için tek otorite kutsal kitap ve Halakhadır. Post-Siyonizm seküler orta sinıfları temsil ederken, neo-Siyonizm işgal altındaki topraklardaki ve Doğu Kudüs’teki yerleşimcileri temsil eder (Ram, 2005b, s.27).

İsrail'de bugün neo-Siyonist ideoloji gerek kamuoyunda gerekse siyasette hâkim konuma gelmiştir. Bu durum Filistin sorununun çözümüne olumsuz bir şekilde yansıdığı gibi İsrail hükümeti bugün her zamankinden daha pervasız bir şekilde siyasi kararlar alarak, uluslararası hukuku ve normları eskisine göre çok daha fazla hiçe sayarak hareket etmektedir. Bu durumun geçici mi kalıcı mı olduğunu söylemek zordur. Ancak kesin olan bundan sonraki süreçte İsrail kimliğini ve rejimini hangi siyasi kültürün galip geleceği belirleyecek olduğudur.

\section{Kaynakça}

Aronoff, M. J. (1988). The Failure of Israel's Labor Party and the Emergence of Gush Emunim. In K. Lawson, \& P. H. Merkl, When Parties Fail: Emerging Alternative Organizations (pp. 309-337). New Jersey: Princeton University Press.

Avineri, S. (1981). The Making of Modern Zionism: The Intellectual Origins of the Jewish State. New York: Basic Books.

Avruch, K. A. (1979). Traditionalizing Israeli Nationalism: The Development of Gush Emunim. Political Psychology, 1(1), pp. 47-57.

Ben-Moshe, D. (2004). Post-Zionism in the Oslo Era and the Implications for the Diaspora. Israel Affairs, 10(1-2), 313-336.

Berent, M. (2015, Winter). Does Israel Have a Navel?. Israel Studies Review, 30(2), pp. 28-49. 
Çağlayan, S. (2004). İsrail Sözlüğü. İstanbul: İletişim.

Dieckhoff, A. (1993). L'Invention d'Une Nation: Israel et la Modernité Politique. Paris: Gallimard.

Einav, O. (2018). Dönüm Noktası: 'Savaşanların Sözü’ Kitabı ile ‘Büyük İsrail' Hareketinin İsrail Söylemi Üzerindeki Etkisi. A. Kurz, K. Michael, \& G. Siboni içinde, Altı Gün, Elli Yıl: Haziran 1967 Savaşı ve Sonrası (s. 261-272). Tel Aviv: İsrail Milli Güvenlik Çalışmaları Enstitüsü. [İbranice]

Encyclopedia of the Middle East. (2019, October 25). Retrieved from Encyclopedia of the Middle East: http://www.mideastweb.org/

Ersoy, T. (2018). İsrailli Olmak: Kolektif Bir Kimlik Geliștirmenin Zorlukları. Türkiye Ortadoğu Çalışmaları Dergisi, 5(1), 73-100.

Finkelstein, N. H. (1987). Theodor Herzl. New York: Franklin Watts.

Flapan, S. (1987). The Birth of Israel: Myths and Realities. London: Croom Helm.

Gelber, Y. (1999). Post-Zionism - Ideology and Practice. Israel Studies Bulletin, 15(1), 5-10.

Greilsammer, I. (2012). The New Historians of Israel and their Political Involvement. Bulletin du Centre de recherce français à Jerusalem (23). [online]

Gutierrez, J. M. (2017). The Rise of the Inquisition: An Introduction to the Spanish and Portuguese Inquisitions. Modi'in: Yaron Publishing.

Halpern, B., \& Reinharz, J. (1998). Zionism and the Creation of A New Society. London: University Press of New England.

Herzl, T. (1988). The Jewish State. New York: Dover Publications.

Johnson, P. (1988). A History of Jews. New York: Harper Perennial.

Kelman, H. C. (1998). Israel in Transition from Zionism to Post-Zionism. The Annales of the American Academy of Political Science, 555, 46-61.

Khalidi, W. (1983). The Jewish-Ottoman Land Company: Herzl's Blueprint for the Colonization of Palestine. Journal of Palestine Studies, 22(1), pp. 30-47.

Kramer, G. (2008). A History of Palestine. Princeton: Princeton University Press.

Laqueur, W. (1972). A History of Zionism: From French Revolution to the Establishment of the State of Israel. New York: Schocken.

Lazare, B. (1981)). L'antisémitisme: Son Histoire et Ses Causes. Paris: E.D.I.

Levy, R. S. (2010). Political Antisemitism in Germany and Austria, 1848-1914. In A. S. Lindemann, \& R. S. Levy, Antisemitism: A History (pp. 121-135). Oxford: Oxford University Press.

Ovendale, R. (2004). The Origins of the Arab Israeli Wars. London: Routledge.

Pappe, I. (2007). Modern Filistin Tarihi: Tek Ülke İki Halk. (N. Plümer, Çev.) İstanbul: Phoenix Yayınevi.

Pappe, I. (2014). The Idea of Israel: A History of Power and Knowledge. London: Verso.

Rabkin, Y. M. (2014). Yahudilerin Siyonizm Karşıtliğı. (Ş. Tokel, Çev.) İstanbul: İletişim.

Ram, U. (2002). Historiosphical Foundations of the Historical Strife in Israel. In A. Shapira, \& D. Penslar, Israeli Historical Revisionism: from left to right (pp. 43-61). London: Routledge.

Ram, U. (2005a). Post-Zionist Studies of Israel: The First Decade. Israel Studies Forum, 20(2), 22-45.

Ram, U. (2005b). Jerusalem, Tel Aviv and the Bifurcation of Israel. International Journal of Politics, Culture and Society, 19(1/2), pp. 21-33.

Rouhana, N. N. (1997). Palestinian Citizens in an Ethnic State: Identities in Conflict. New Haven: Yale University Press.

Schneer, J. (2015). Balfour Deklarasyonu: Arap-İsrail Çatışmasının Kökenleri. (A. C. Akkoyunlu, Çev.) İstanbul: Kırmız Kedi Yayınları. 
Selçuk, S. (2006). Dreyfus Davası: Dünyaca Unutulmayan Yargılama Hatası. Ankara: İmge.

Shapira, A. (2012). Israel: A History. (A. Berris, Trans.) Waltham: Brandeis University Press.

Shimoni, G. (1995). The Zionist Ideology. Hanover: University Press of New England.

Shlaim, A. (2000). Iron Wall: Israel and the Arab World. London: Penguin Books.

Silberstein, L. J. (1999). The Post-Zionism Debates: Knowledge and Power in Israeli Culture. London: Routledge.

Smith, A. (1996). Memory and Modernity: Reflections on Ernest Gellner's Theory of Nationalism. Nations and Nationalism, 2(3), pp. 371-388.

Smith, A. (2007). Milli Kimlik. (B. S. Şener, Çev.) İstanbul: İletişim.

Smith, A. (2017). Etno-Sembolizm ve Milliyetçilik. (B. F. Çallı, Çev.) İstanbul: Alfa.

Sprinzak, E. (1981). Gush Emunim: The Tip of the Iceberg. Jerusalem Quarterly (21), pp. 28-47.

Uriel, M. (2014). Büyük İsrail Hareketi’nin Yahudiye ve Samariye’de Yerleşim Hususundaki Rolü. 4. Hebron Araştırma Konferansı Bildiri Kitabı (s. 89-102). Hebron: Hebron Midraş. [İbranice]

Waxman, Chaim I. (9997). Critical Sociology and the End of Ideology in Israel. Israel Studies 2 (1), pp.94210.

Weissbrod, L. (1982). Gush Emunim ideology — from religious doctrine to political action. Middle Eastern Studies, 18(3), pp. 265-275. 


\section{The Ideological Reflection of Liberal Democracy and Ethnic Nationalism in Israel: Post-Zionism and Neo-Zionism}

\section{Tuğçe ERSOY CEYLAN* iD}

The establishment of Israel is an historical moment, a ground-breaking development in Jewish history. The ideational background that enabled the establishment of Israel is Jewish nationalism qualified as Zionism. In this respect, it is essential to indicate that the emergence of Zionism as an action plan to be followed by the Jews is a turning point on its own. Zionism has not only transformed the political and socio-economic positions of the Jews, but also it has an impact the conduct of every community, religious movement, association and institution. Zionism was not the first intellectual practice developed as a solution to the situation in which Jews lived. However, owing both to the Zeitgeist and the ambition and perseverance of its founder, Theodor Herzl (1860-1914); Zionism has become the principal ideology that established Israel.

Therefore, has Zionism fulfilled its mission which was self-determination and creating a state for the Jews? It is possible to assert that Zionism as a plan of action has accomplished its purpose but as an ideology it still persists. The questions asked within the framework of the debate that Zionism petered out have paved the way for new Zionisms. These new approaches have been shaped around the discussions on the fundamentals of Zionism, thus on the very foundation of the state of Israel. Especially, having reinterpreted the state-building narrative, a group of researchers called new historians and post-Zionists have been perceived by some circles in Israel as an existential threat to the state. Hence, the aim of the study is to analyze comparatively the post-Zionist approach that first emerged within the academic circles in Israel and the neoZionist trend which was placed as counter argument against post-Zionism. As the manifestations of liberal democracy (neo-Zionism) and ethnic separatism (neo-Zionism), these approaches are examined via process tracing from their appearance to modern day within the analytical perspective of historical sociology. The main argument of the article is that at the center of these two ideological approaches which represents two counter poles of the Israeli society which is deeply divided with identity cleavages, there are discrepancies vis-à-vis the policies carried out against the Palestinians both living in the occupied territories and in Israel.

İzmir Demokrasi University, Department of International Relations, E-mail: tugce.ersoy@idu.edu.tr 
The article proceeds in three steps. In the first section, the emergence of Zionism is scrutinized within the historical process. Second section deals with the new arguments criticizing the nature of Zionism and the character of the state that sprang at the Academy following the establishment of Israel; by doing so the climate where post-Zionist approach has come into being is revealed. The last section engages in addressing the policies and practices that have enabled the occurrence of neo-Zionism. After introducing the emergence and main arguments of the two contradictory positions, the article seeks to put forward a general framework about the direction of the ideological cleavages within the Israeli society.

In 1896 Theodor Herzl, the founder of Zionism announced in his book Jewish State that the only solution to the Jewish problem would be the creation of a state in Palestine. The emphasis here was that the state should have fundamentally and particularly a Jewish character (Herzl, 1988, p. 123-152). Indeed, this way of thinking would constitute the backbone of the attitudes and positions vis-à-vis Palestinians who would continue to live in Palestine after the creation of the state and this would pave the way for the perception of the Palestinians as a threat to the Jewish character of the state.

In this respect, one could argue that Zionism being a nationalist answer to the rising antiSemitism and racism in Europe has become a colonialist movement after the decision to apply its vision of revitalizing the nation in Palestine (Pappe, 2007, p.33). This critical stance against the Zionist ideology has been validated by some Israeli academics and journalists during the ethnic cleansing in 1947 and the Six Day War of 1967 that culminated with the occupying of Palestinian lands. Thus, those circles have put forth a new kind of thinking. The new interpretation taking shape around criticizing of the persecution of the Palestinians in the occupied territories and the discrimination against the Palestinian citizens of Israel has come to be known as post-Zionism.

The manifestations of post-Zionism as a counter-hegemonic discourse were primarily academic. Many issues deemed as taboos were brought into question: Zionism as colonialism, Nakba, the discrimination against the Palestinian citizens of Israel, the manipulation of Holocaust and etc. (Pappe, 2014, p.127). The historians who deal critically with these issues were designated as 'new historians' (Greilsammer, 2012). This new kind of intellectual thinking was qualified as postZionism. However, even today there is no common definition of the approach. Kelman embraces post-Zionism both normatively and descriptively. In this respect, post-Zionism refers to the ongoing gradual ideological transformation and it displays the perspective of the Jews about this transformation. Thus, the post-Zionism is composed of the discourses of transformations from exclusion to pluralism, from discrimination to equality and cooperation, from isolationism and hostility to integration (Kelman, 1998, p.47).

On the other hand, there are powerful opponents of post-Zionism, one is neo-Zionism. It might be contended that these two approaches represent the counter poles in the Israeli political culture today. The antagonism between post-Zionism and neo-Zionism is, so to speak, a clash of civilizations: a clash between universal, cosmopolitan and liberalist post-Zionism and chauvinist, 
racist and particularist neo-Zionsim (Ram, 2005a, p.35-6). Before becoming popular in the 1990s as neo-Zionism, there were predecessors of this ideological thinking. The Movement for Greater Israel (Eretz Yisrael HaŞleima) and the settler movement, the Bloc of the Believers (Gush Emunim) constitute the foundations of the neo-Zionist ideology which represents a certain category of the Israeli society.

Despite its foundations go back before 1990s, neo-Zionism is a new concept that portrays the political stance against post-Zionism. Put differently, it is the general qualification of the religiouspolitical ideology that sprang following the 1967 war. Uri Ram has defined this phenomenon which developed in parallel with and in opposition to post-Zionism as a political-cultural tendency which is exclusive, nationalist, racist, anti-democratic (2002, p.57).

After the consolidation of these approaches as the poles of identity, there have emerged three interpretations of Zionism in Israel: Classical Zionism focuses on realizing its political agenda via Jewish and democratic Israel. Post-Zionism adopting cosmopolitan and liberal view, envisions a state in which every living person has equal rights and are accepted as equal citizens. Notwithstanding, neo-Zionism, embarking on ethno-religious tendency, has created a racist and discriminatory political identity which excludes all the groups except Jews (Ram, 2005b, p.26).

Today, neo-Zionism has self-claimed its victory both in politics and in public opinion. This situation is negatively echoed on the solution of the Israeli-Palestinian conflict. Besides, Israeli government is acting ever more reckless than any time and taking political decisions in defiance of international law and norms. It is hard to tell whether this political stance is temporary or permanent. But which is certain is that Israeli identity and regime would be determined according to the certain victory of one of these political cultures: post-Zionist or neo-Zionist? 